\title{
豊臣秀頼の作事体制について \\ A STUDY OF SAKUZI STRUCTURE OF TOYOTOMI HIDEYORI
}

\author{
木 村 展子* \\ Nobuko KIMURA
}

\begin{abstract}
Hideyori constructed a lot of temples and shrines. Investigation into munahuda and bokushomei of these temples and shrines makes clear the character of sakuzi structure of Hideyori. Among them, the forms of sakuzi projects are divided into two. One is carpenters and craftman dispatched by Toyotomi performed sakuzi(A), and the other is carpenters belonging each temples and local carpenters performed it as the main constituents(B), with the money and magistrates of Toyotomi. By examining the forms of sakuzi projects by Hideyori, it's found that form(A) was taken in many cases with active mobilization, but form(B) also existed widely. And the chief carpenter who generally direct the sakuzi project like Nakai Masakiyo did not exist. It suggests the limit of sakuzi structure of Hideyori and it is doubtful it worked entirely as an organization.
\end{abstract}

Keywords : carpenter, sakuzi, Toyotomi Hideyori, Momoyama era 大工、作事、豊臣秀頼、桃山時代

\section{1 .はじめに}

安土城で天下普請が始まってのち、中井正清が自分の体制を大体 確立する慶長十年(1605)頃までの約 25 年間は、座に代表される中 世的な組織が崩壊し、町大工・閃閂大工・新興大工などあらゆる大 工の再編成が進められ、最終的には正清によって一元化される過程 であった。

桃山時代 ${ }^{1)}$ に造営された数多くの城郭・寺社の造営主体は主に徳 川氏と豊臣氏である。徳川氏の作事組織について流、幕藩体制確立 以降の作事方はもちろんのこと、中井家に関しても、中井家文書に より数多くの研究がある。一方、豊臣秀吉、秀頼親子が畿内にとど まらず多くの寺社を造営したことは有名であるが、秀吉が造営した 建築物はほとんど現存していない。秀頼の造営した寺社は半数近く が現存しているが、秀吉、秀頼期を通じて造営文書の類は残ってお らず、絶対的な 1 次史料の不足から作事糄成などはわかっていな い。現時点では、中井家のように体系的に豊臣氏の作事組織を解明 することは不可能である。しかし、秀頼の造営寺社に関しては棟札 や墨書銘などが発見されている。史料としての限界はあるが、棟札 や墨書銘などを検討することにより、秀頼の作事体制の性格を明ら かにしたい。

\section{2 .秀頼の寺社造営における作事方式}

豊臣秀頼の造営寺社について調查した結果、現在のところ橋梁を 含めて 90 寺社が判明した ${ }^{2)}$ 。それらの寺社を概観すると、地域的 には、山城と領国の摄河泉が最も多く、ついで大和、近江、その 他、伊勢、熊野、出雲、尾張などの遠隔地にも存在する。時期的に は慶長五年(1600)以降本格化し、慶長十三、四年を境に急激に減少 する。

これら寺社の造営は多くの場合、当然、豊臣氏が奉行と大工、諸 職人を派遣し作事を行っている。しかし、棟札や文書史料からは寺 家大工や地元の大工の関与しか認められない場合もある。横田冬彦 氏は、慶長期の寺社の作事を経営主体や寺家大工の関わり方から見 て、寺院側の経営で寺家大工が行うものと、政権側が費用を下行し て施主となり奉行を派遣するものとがあり、さらに後者は寺家大工 が行うものと派遣された大工が行うものとがあることを明らかにし たが ${ }^{3)}$ 、秀頼の作事においても同様に、作事方式は二種類に大別で きる。すなわち、豊臣氏が費用を下行し、奉行を派遺するが、大工 や諸職人も派遺し作事を行う場合（A）と、寺家大工や地元の大工 が主体となって作事を行う場合（B）である。秀頼の造営寺社にお ける作事方式の別、担当奉行、大工等は表 1 のようになる。

まずB方式の作事について見ていくと、山城では、慶長十一年 
表 1 秀頼寺社造営における作事方式・奉行・大工

○豊臣方大工（請負の可能性あり） $\triangle$ 寺社方大工 $\times$ 不明

\begin{tabular}{|c|c|c|c|c|c|c|c|c|c|c|}
\hline 地域 & 作 & 建策物名 & 方式 & 規模 & 工事 & 奉行 1 & 奉行 2 & 大I 1 & 大I. 2 & 備考 \\
\hline \multirow[t]{30}{*}{ 山城 } & 度長 4 年 & 曹国麻 & A & 全潇 & 新策 & 前田玄以 & 木食庆其 & & & 秀頼帠建のためA方式 \\
\hline & & 石清水八轃宫若宮殿社 & A & 全籸 & 再建 & 大野治骎 & & & & 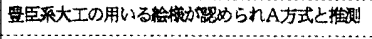 \\
\hline & 震長 5 年 & 配酲寺金堂 & A & 数梀 & 移策 & 前田去以 & 木金芯其 & 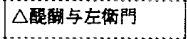 & 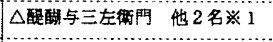 & \\
\hline & & 方広寺七重塔・賄堂・趣廊 & A & 数 & 新案 & & & & & 券吉期建のためA方式 \\
\hline & & 曋国朝楼門 & A & 全粎 & 移案 & & & & & 秀禎臫建のためA方式 \\
\hline & 慶長 6 年 & 法国寺 & A & 全梾 & 新究 & & & & & 秀㛲創建のためA方式 \\
\hline & 骨 7 年 & 清暯寺积迦堂 & 不明 & 1 模 & 再建 & & & $\therefore$ & & \\
\hline & 年 8 & 取光院本堂 & 不明 & 1 粎 & 再建 & & & & & \\
\hline & & 東寺金堂 & B & 数粎 & 再建 & 片相且元 & 㸓 & 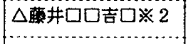 & & \\
\hline & 度長 9 年 & 簧院 & 不明 & 不明 & 再建 & & & & & \\
\hline & 度且 10 年 & 金我光明寺阿你触堂 & 不明 & 数粎 & 再建 & 吕城豊盛 & & & & \\
\hline & & 東寺南大間 & 不明 & 数㙌 & 再娖 & & 势举 & & & \\
\hline & & 石清水八幡宫大塔 & 不明 & 全梾 & 再速 & & & & & \\
\hline & & 相国寺法堂・睡楼 & 不明 & 数棟 & 再建 & & & & & \\
\hline & 要 1114 & 安果陦院多宝塔 & B & 1 粎 & 再速 & 片桐且元 & & 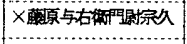 & & 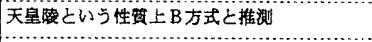 \\
\hline & & 高台寺 & 不明 & 不明 & 称理 & 片桐貟䀨 & & & & \\
\hline & & 兵正極楽寺本堂 & 不明 & 1 槏 & 再建 & 片柏貝隆 & & & & \\
\hline & & 石清水八幡宫 & A & 全梀 & 再建 & 小出吉正 & & & & \\
\hline & & 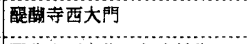 & A & 数梂 & 再速 & 片柇且元 & 建暗光里 & 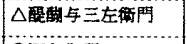 & 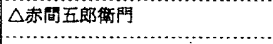 & $※ 3$ \\
\hline & & 醮酳寺五大堂. 如意輪堂 & A & 数㙌 & 再建 & 片相且元 & 建暗光里 & O确左盢聞 & . & \\
\hline & & 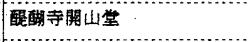 & $\mathrm{A}$ & 数堜 & 再建 & 片桐且元 & 角西則是 & 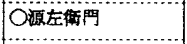 & & \\
\hline & & 等持院 & 不明 & 不明 & 再建 & 片桐且元 & & & & . \\
\hline & & 南禅寺法堂 & B & 1 粎 & 再建 & 片桐且元 & 片桐嘪隆 & 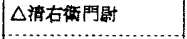 & & \\
\hline & & 北野経王堂 & 不明 & 1 棟 & 再建 & & & . & & \\
\hline & 侵長12年 & 北野天浩宫 & A & 全秤 & 再建 & 片相且元 & 荒不䐒太 & ○森田和泉守墨次 & $\Delta$ 岩會五郎左耻 & \\
\hline & & 与杼神社 & A & 数粎 & 再建 & 片相且元 & & & & \\
\hline & 要 13 年 & 䗆馬寺 & 不明 & 全粎 & 再建 & & & & & \\
\hline & 序曼 15 年 & 由的神社择殿 & $B$ & 1 棟 & 再建 & 建部光量 & & & & 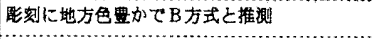 \\
\hline & 害長 18 年 & 金我光明寺御影堂 & 不明 & 数坢 & 再建 & 宮城曋盛 & & & & \\
\hline & & 方后寺大仏段 & A & 数槏 & 再建 & 片相且元 & & 中井大和守正清 & 中井五左政門 & 公湭大I \\
\hline \multirow[t]{26}{*}{ 捉津 } & 陵長 5 年 & 四天王寺 & 不明 & 全㙌 & 再建 & 戏野長政 & 小出秀政 & & & \\
\hline & 度長 6 年 & 輠名野神社 & B & 不明 & 再建 & 長照法印 & & & & \\
\hline & 慶髙 7 年 & 硕磨寺本堂 & A & 数梾 & 再建 & 片桐且元 & 津田腎閑 & O五兵㸆 & O㱛兵街 & \\
\hline & & 金能寺開山堂 & 不明 & 1 粎 & 再䢖 & & & & & \\
\hline & 8 & 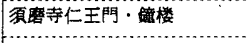 & A & 数林 & 舟建 & 片桐且元 & 津田患閏 & & & \\
\hline & & 総持寺 & 不明 & 全粎. & 再健 & 片桐且元 & & & & \\
\hline & & 中山寺 & A & 全粎 & 再建 & 楅山重政 & 干賀消局 & O藤右得閶 & & \\
\hline & & 箕面寺本堂・六坊 & 不明 & 数㙌 & 再建 & & & & & \\
\hline & & 五造榴荷神社 & 不明 & 全神 & 票建 & 片相且元 & $\begin{array}{l}\text { 伊䁬則長 } \\
\end{array}$ & & & \\
\hline & 猃長 9 年 & 腾㢆寺本堂 & 不明 & 1 梾 & 再建 & & & 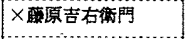 & & \\
\hline & & 本山寺 & 不明 & 全楔 & 再建 & & & & & \\
\hline & & 西宮神社表大間 & 不明 & 数梾 & 再建 & & & & & \\
\hline & & 県服神社 & A & 全楼 & 再建 & 片楬且元 & 妍新介 & ○屋与左侢門正吉 & & \\
\hline & & 伊居太神社 & A & 全梀 & 再连 & 片柇且元 & 4 & 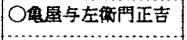 & & \\
\hline & & 貄川䅦 & 不明 & 1 慗 & 再建 & & & & & \\
\hline & 長 10 年 & 多田院 & 不明 & 全梾 & 再建 & 建部光里 & & & & \\
\hline & 震長 111 年 & 七宮大明神社本殷 & B & 1 粎 & 再建 & 片椾且元 & & & & 扫宫大明神社貶 よりB方式 \\
\hline & & 生国魄神社 & 不明 & 全梾 & 再建 & 片桐且元 & & & & $\therefore$ \\
\hline & & 偁土寺本堂 & A & 1 粎 & 再建 & 片相旦元 & 荒木缕太 & O和泉守 & & \\
\hline & & 法安寺 & 不明 & 全㙌 & 再建 & 片桶且元 & & & & \\
\hline & 慶 12 年 & 住吉大社 & A & 全㙌 & 再建 & 片桐且元 & 荒木有太 & O电屋与左䚘閏 & 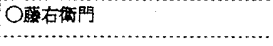 & \\
\hline & $\cdots$ & 生根神社本殿 - 择㷉 & A & 数植 & 再建 & 片椔且元 & & & & 倠吉松莱大眍」よりA式 \\
\hline & & 住吉神富寺 & A & 全蚻 & 再隹 & 片相且元 & & O但馬守 & $\because$ & $\therefore$ \\
\hline & 長 14 年 & 西宫神社本殿 & 不明 & 数㙌 & 再建 & 片桶且元 & & & & \\
\hline & 度表 18 年 & 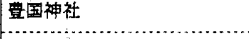 & A & 全棟 & 新筮 & 片棆且元 & & & & 秀頼㓱建のためA方式 \\
\hline & & & & & & & & & & \\
\hline \multirow[t]{7}{*}{ 河内 } & 眘長 6 年 & 芴井寺四脚門 & 不明 & 全梀 & 再建 & 伊碷則長 & & & & \\
\hline & 度長 7 年 & 片枆神社 & A & 全被 & 再建 & 标相且元 & 松山淁曼 & O电左语門正吉 & & \\
\hline & 度 8 年 & 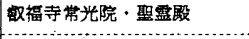 & 不明 & 数棟 & 再越 & 伊两䀧則長 & & & & \\
\hline & $\cdot$ & 二宫神社 & A & 全梀 & 再建 & 片相且元 & 松山義長 & O里属与左衙門正吉 & & \\
\hline & 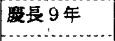 & 昜井寺 & 不明 & 全栖 & 再建 & & & & & \\
\hline & & 玉祖神社 & 不明 & 全桋 & 再建 & 片相且元 & 小出秀政 & & & \\
\hline & 鹿長 10 年 & 校岡神社 & 不明 & 全楼 & 再建 & 乘山重政 & & & & \\
\hline
\end{tabular}




\begin{tabular}{|c|c|c|c|c|c|c|c|c|c|c|}
\hline 地城 & 年 & 建筑物名 & 方式 & 規模 & 工事 & 奉行 1 & 奉行 2 & 大I 1 & 大工 2 & 備考 \\
\hline \multirow[t]{5}{*}{ 河内 } & 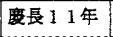 & 金㓮寺 & A & 全㙌 & 格理 & 片桐且元 & 吉田保好 & O居与左街門正吉 & O腾次郎 他 & \\
\hline & & 省田八幡宮 & 不明 & 全林 & 再建 & 片桐且元 & 小出客政 & & & \\
\hline & 要長 18 年 & 雎心寺金堂 & B & 数㜛 & 橙理 & 片椅且元 & & $\Delta$ 表完五郎左街門 & 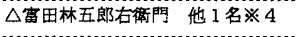 & \\
\hline & & 常光寺 & 不明 & 全梾 & 再建 & 片相且元 & & & & \\
\hline & 庋長 19 年 & 観心寺的梨帝母天堂 & B & 数槙 & 眘替 & 片啊旦元 & & 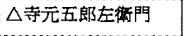 & $\triangle$ 富田林五郎石衛門 把 1 名※ 4 & \\
\hline \multirow{9}{*}{ 和臬 } & 要長 7 年 & 日根神社 & B & 全㙌 & 再建 & 吉田一正 & & 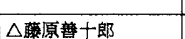 & 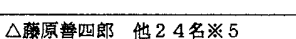 & \\
\hline & & 泉穴睄神社 & B & 数林 & 再建 & 片相亘元 & 藤枝定吉 & 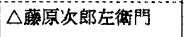 & 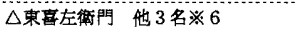 & \\
\hline & & 棈川神社 & B & 不明. & 再建 & & & & & 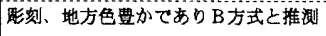 \\
\hline & & 大鳥神社 & 不明 & 不明 & 再建 & & & & & \\
\hline & & 兹眼院 & B & 全槏 & 再建 & 吉田一正 & & 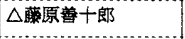 & 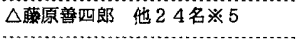 & \\
\hline & & 松尾寺本堂 & 不明 & 1 梾 & 移籍 & 片栖且元 & & & & \\
\hline & 皮長 8 年 & 笵福表本堂 & 不明” & 1 & 雫建 & 小出高政 & 放士更公 & & & \\
\hline & 韯 10 年 & 五社辁社 & 不明 & 不明 & 再建 & & & & & \\
\hline & 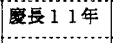 & 整神社 & A & 全㙌 & 再建 & & & $\mathrm{O}=\mathrm{E}$ & & \\
\hline & & & & & & & & & & \\
\hline \multirow[t]{9}{*}{ 大和 } & 㯖長 6 年 & 法華寺本堂・南門：镂楼 & A & 数菓 & 再建 & 片椅且元 & & & & \\
\hline & 歪 8 年 & 休同八幡神社 & A & 全模 & 再建 & 片桐且元 & 梅户取右衛門 & O贯多越後守清次 & O害多助作 他 3 名 7 & \\
\hline & & 神社本殿 & 不明 & 1 模 & 再建 & & & & & \\
\hline & 要長 9 年 & 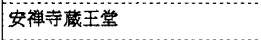 & 不明 & 1 畨 & 再建 & & & & & \\
\hline & & 吉野山大榑 & A & 1 葙 & 再建 & 建部光曋 & & & & \\
\hline & 鹿長 10 年 & 吉野水分神社 & A & 全粎 & 再速 & 建部光亚 & & 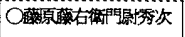 & 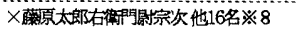 & \\
\hline & & 手向山八幡大塔 & 不明 & 1 畨 & 再建 & 小出吉政 & & & & \\
\hline & & 逢磨寺本堂・開山堂 & 不明 & 数楳 & 再建 & 片相且元 & & & & \\
\hline & 政县 11 年 & 法䧝寺 & B & 全楳 & 格理 & 片桶且元 & 梅户取右䘖間 & $\triangle$ 中井大和守正清 & $\triangle$ 藤原宗右街門宗次 他 3 名 9 & \\
\hline \multirow[t]{18}{*}{ 㨞外 } & 要長 3年 & 冿皇神社南門 & B & 1 粎 & 再建 & 谓岛正則 & & & & 貄煦神社文鲁より B方式 \\
\hline & 長 5 年 & 㗲学院客殿 & B & 1 梀 & 再建 & 毛利短元 & & & & \\
\hline & & 曾光寺如来堂 & 不明 & 1 葙 & 再建 & 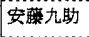 & & & & \\
\hline & 葽長 6 年 & 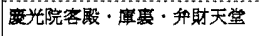 & 不明 & 数楼 & 再速 & 杵相且元 & 檘莱道通 & & & \\
\hline & & 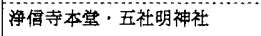 & 不明 & 数模 & 再建 & 伤相且完 & 䨋㷊長介 & & & \\
\hline & 费長 7 年 & 都久夫夫得神社本叞 & $\mathrm{B}$ & 1 粎 & 移栗 & 年相且元 & 䨋森長介 & & & \\
\hline & & 石山寺 & B & 全槏 & 理 & 片桐且元 & 声山茂右衛門 & $\Delta$ 田中石見守矨久 & $\triangle$ 田中出毁守重次 & \\
\hline & 慶晨 8 年 & 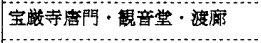 & B & 数楼 & 移要 & 片柏且元 & 雨森長介 & $\Delta$ 㛢守 & $\Delta$ 但馬守 & \\
\hline & & 白繁神社 & A & 全粎 & 再通 & 片桐且元 & 雨森猥介 & O藤原与三兵很 & & \\
\hline & & 育算椤表本堂 & 不明 & 11 & 攸理 & 栈野幸長 & 小出吉政 & & & \\
\hline & 骨 9 年 & 延厤寺熼川中堂 & 不明 & 1 榲 & 再建 & 片樎兵隊 & & & & \\
\hline & & 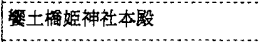 & 不明 & 1 楼 & 再建 & 雨森長介 & 安养寺案兵街 & & & \\
\hline & & 䇏見寺三重塔他 & 不明 & 数植 & 再建 & 蟣田有楽 & & & & \\
\hline & 鹿是 11 年 & 整田神宫寺 & 不明 & 数槙 & 再建 & 片㭬且完 & & & & \\
\hline & & 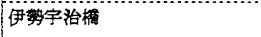 & 不明 & 1 楼 & 再建 & 片粨且元 & & & & \\
\hline & 12 年 & 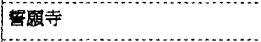 & 不明 & 全植 & 再建 & & & & & \\
\hline & 要長 14 年 & 出塞大社本良 & A & 数楼 & 再建 & 片相且元 & 掘尾吉媾 & O桃木久左衙門 & & \\
\hline & 聚 19 年 & 期野本宽大社 & 不明 & 全槏 & 票透 & 栈野莘長 & & & & \\
\hline
\end{tabular}

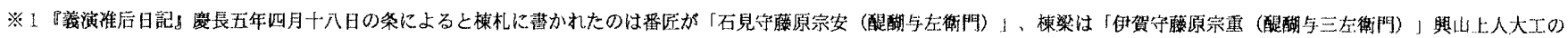
「土传守滕原幸宗」「滕原宗清」である。

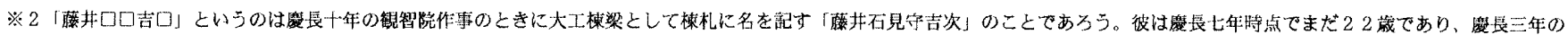

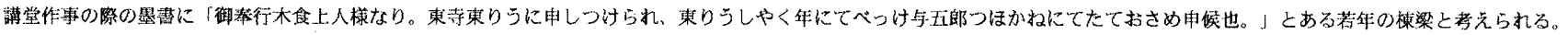

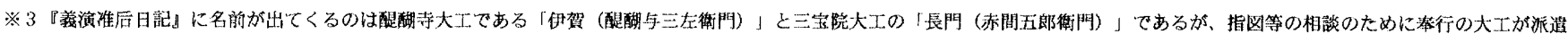
され、作事は「大报に亚く木作」が行むれているのでA方式である。

※4 楝札によるとこ机以外に「大子勝右街門」加いる。

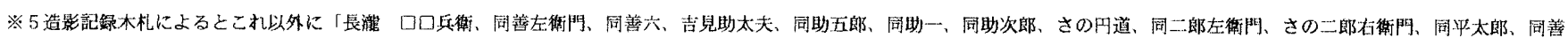

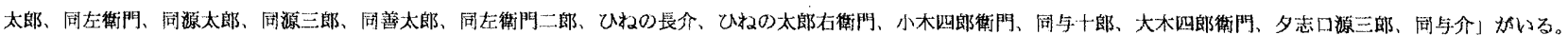

※6棟札によるとこれ以外に「滕原又术!「藤原与介」「東左近次郎」がいま。

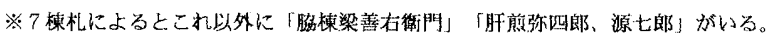

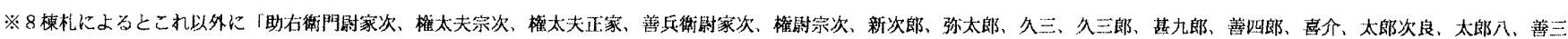

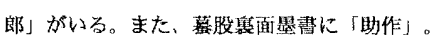

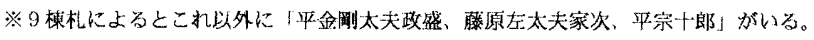


(1606)の南禅寺法堂があげられる。作事奉行であった片桐且元、貞 隆の書状 ${ }^{4)}$ によると大工棟梁は清右衛門尉と考えられる。清右衛門 尉というのは南禅寺寺家大工の平松清右衛門のことで、材木の検分 などすべて清右衛門が行っている。少なくとも前記書状からは秀頼 側の大工の関与は認められない。

摂河泉では特に和泉において B方式の作事が多い。文書史料はな いが、慶長七年(1602)造営の積川神社には、泉南から和歌山にかけ て分布する貝類や流水に筆を題材とした蟇股䧓刻があり、地元の大 工が作事に当たったものと思われる。

同年造営の日根神社と神宮寺の慈眼院の大工は造営記録木柇 ${ }^{5)}$ に よって判明している。大工棟梁は長滝庄堂前の藤原善十郎、彫物は その一門の善四郎、彩色は中庄の多賀佐馬助、桧皮大工は府（中） の善左衛門、鍛冶は日根野村の左衛門である。日根野は日根神社の 所在地、長滝と中庄は日根野より海側、府中はやや離れるが現在の 和泉市にある。その他 24 人の大工名が記載されていて、やはり長 滝や日根野、佐野などすべて地元の大工である。さらに 9 人の杣大 工も日根野と日根野より山側に位置する上郷の大工である。

同年造営の泉穴師神社は各時代の棟札がよく残っており、慶長度 造営の大工も棟札 ${ }^{6)}$ によって知ることができる。奉行の藤枝与左衛 門尉定吉は大津の郷士、大工の藤原次郎左衛門や又市、与助、東喜 左衛門は、いずれも地元府中の住人である。

摂津・河内は大坂城下ということもあり、大工や諸職人まで派遣 しているA方式が多い。例外のひとつに慶長十八年(1613)の観心寺 金堂がある。棟札 ”)り棟梁大工は富田林五郎右衛門、大工は寺元五 郎左衛門、太子勝右衛門と判明しているが、これらの大工はいずれ も地元の大工であると考えられる。というのも観心寺の所在地は河 内長野市寺元、また観心寺は富田林市との市境にある。太子勝右衛 門の「太子」については、やや離れるが、富田林市を挟んで寺元の 反対側に太子町がある。観心寺は金堂は修理、訶梨帝母天堂は屋根 蒀替と軽微な工事であり ${ }^{8)}$ 第 2 次方広寺大仏殿造営中という事情も 重なって地元の大工によって作事が行われたものであろう。

近江では、慶長七年(1602)造営の石山寺があげられる。『石山年 代記』によよる大工は田中石見守光久と弟の出雲守藤原重次であ る。彼等はそれぞれ石山と平津の住人であり地元の大工である。

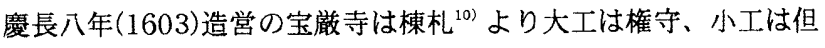
馬守であるとわかるが、権守というのは竹生島の御大工、浅井郡富 田村の阿部氏、但馬守は同じく富田村の西島氏のことであり ${ }^{11}$ 、地 元の大工である。前年造営の都久夫須麻神社に携わったのも宝簃寺 同様、大工は権守、小工は但馬守であったと考えられる。

A方式の作事についてみると、大規模な寺社で寺家大工がいる時 は共同作業となることが多い。そして、その関係は時々で異なる。 例えば、醍醐寺金堂の場合は、寺家大工は応其の下での労働編成に 組み入れられたにもかかわらす、形式的には棟札の最初に記されて いる ${ }^{12)}$ 。北野天満宮では門跡大工と松梅院大工の争いから上棟式の 槌打ちは秀頼大工の森田和泉守重次が行い ${ }^{13)}$ 、棟札 ${ }^{14)}$ にも最初に名 前が記されている。住吉大社では社家大工の宗兵衛と与兵衛がいる が、釿始は秀頼派逼の大工の亀屋与左衛門が行っている

また、権門寺社では数年にわたって伽藍が整備されることが多い が、同一寺院ではいつも同じ作事方式をとっていたというわけでは
ない。前述の醍醐寺の場合、秀吉、秀頼の二代にわたって再建され るが、『義演准后日記』によると慶長二年(1597) の秀吉による五重 塔の修理は寺家大工の醍醐与左衛門と醍醐与三左衛門がおこなう B 方式 ${ }^{16)}$ 、慶長三年(1598)の北政所による三宝院造営も門跡大工で禁 裏大工でもあった鑓屋三右衛門・彦右衛門と下代の赤間五郎衛門が

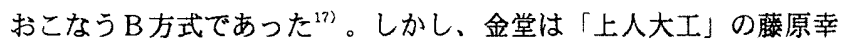
宗、宗清を中心として寺家大工の醍醐与左衛門と醍醐与三左衛門も 加わったA方式 ${ }^{18)}$ 、さらに慶長十一年（1606)の山上加藍では、

「奉行ノ大工」源左衛門を中心としたA方式である ${ }^{19}$ 。園城寺でも 慶長四年(1599)の金堂はA方式であったが20)、翌五年(1600)の衔学 院客殿は寺家大工が作事に当たった可能性があり ${ }^{21)}$ そゔあれば $\mathrm{B}$ 方式であった。

秀頼の寺社造営における作事方式を検討した結果、多くの場合、 奉行による積極的な動員が行われるA方式であるが、それ以外に B 方式が広範囲に存在していることがわかる。さらにA方式の場合で も大規模作事の時は寺家大工との共同作事となっている。このこと は秀頼の作事体制の限界を椝わせるものであるといえよう。

\section{3.秀頼の寺社造営における棟梁}

次に記録類から秀頼側から派遣されたと判明している大工につい て検討する。この場合、作事方式はA方式である。

㫣屋与左衛門 造営件数が最も多いのは亀屋与左衛門である。慶 長七年(1602)の片埜神社と慶長八年(1603)の二宮神社では総奉行片 桐且元、奉行松山義長、富田盛次の下で作事にあたり ${ }^{22)}$ 、統く瞢長 九年(1604)の伊居太神社と呉服神社では総奉行片桐且元、奉行牧新 介、藤林与左衛門守吉の下で作事に当たっている ${ }^{23)}$ 。いずれの場合 も本殿ばかりでなく拝殿、築地、鳥居、門、摂社、神鐉所、社務所 等境内全体の社殿を造営している。

また、それらの作事と相前後して始められ、慶長十一年(1606)ま で続く金剛寺全域の改修工事にも携わっている。楼門の東南隅木墨 書に「大阪住人 亀屋与左衛門之内／勝治郎式拾壳歳合作之也相番 匠 /同与三五郎同久次郎也 /高向勝次郎 $/ \square$ 時慶長拾年九月廿八日

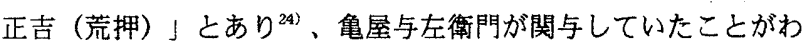
かる。その時の作事の内容は、金堂、多宝塔、食堂、鐘楼、楼門は 解体修理、御影堂並びに観月亭、薬師堂、五仏堂は旧材も転用した 再建、摩尼院、北門、南門、䦥伽井屋、法具蔵、護摩堂、鎮守社の 丹生高野明神社と水分明神社は新造である ${ }^{25)}$ 。多宝塔は心柱畦書に 「御大工源丞 梶藤右衛門 森島喜三郎 脇大工与右衛門 林口三 郎 森口蔵」とあり ${ }^{26)}$ 、御大工源丞は寺家大工と思われるが、脇大 工与右衛門は後に述べる住吉大社作事にあたる亀屋与右衛門の可能 性もある27/。このほか食堂の軒唐破風下に牡丹唐草の㱳股がある が、この牡丹は片埜神社本殿身舎の牡丹とほほ同じ形状であり、食 堂の修理も亀屋与左衛門とその一門が当たったと思われる。いずれ にせよ、規模が大きかったこともあり、金剛寺では寺家大工との共 同作業であったようである。

『住吉松葉大記』 ${ }^{28)}$ によると、与左衛門は、同年十月には総奉行 片桐且元、奉行吉田次左衛門、片桐貞隆の下で住吉大社の造営に当 たる。本殿は惪替、西大鳥居は修理であったが、西大門、南大門、 神典舎、神馬屋、弊殿、楽屋、御旅所、石舞台、神楽所、北、南東 
の大鳥居、廻廊、高倉、浄土寺の本堂、庫裹、神宮寺の東西の塔、 東西南北それぞれの門、築地、常行三昧堂法華三昧堂、僧坊を再建 するという大規模なものであった。「泉州堺亀屋与左衛門、与右衛 門」が大工棟梁で、釿始は当社の「総大工」宗兵衛と「権大工」与 兵衛がいるにもかかわらず、秀頼の造営ゆえ急屋与左衛門が行って いる。与左衛門と共に記される与右衛門は㧍そらく与左衛門の息子 か弟と考えられる。

慶長八年(1603)から立て続けに亀屋与左衛門は寺社の造営を行っ ているが、与左衛門には多くの配下の大工がいて、数多くの寺社造 営をこなす能力があったと思われる。現存しているのは片埜神社本 殿、南門、金岡寺食堂、楼門、住吉大社南大門、楽所、石舞台の夕 である。片禁神社本殿は建築郕刻は堅実であるが、当時南大阪で流 行していた二重虹梁大瓶束を妻組に取り入れ華やかである。金剛寺 の改修においては構造的な補強ばかりでなく、食堂で洼風化した柱 表面を削り直したり内外を回転させたり意匠にも配慮した修理をし ている ${ }^{29)}$ 。このような部分に亀屋の特性が見い出される。また、与 左衛門ではないが、広島県三原市にある米山寺の天正四年(1576)の

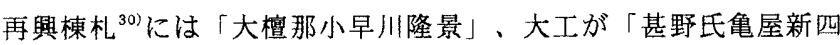
郎」と記されている。「大従泉南堺津撰迎抜萃匠工」と記され、 亀屋一門が当時名の通った大工であったことがわかる。しかし、後 の大坂の大工組にも中井配下にも亀屋姓の大工を見い出すことはで きない。

源左衛門 醍醐寺山上伽藍の作事に当たつた源左衛門は、『義演 准后日記』によると大仏十人棟梁の一人であるという ${ }^{31)}$ 。その出自 は不明で紀伊出身か大和出身かはわからないが、方広寺大仏殿造営 の時に応其によって連れて来られた工匠の一人であることは間違い ない。また、『慶長日件録』にその名が頻出する大工源左衛門と同 一人物であるなら、舟橋秀賢の被官大工でもあった ${ }^{32}$ 。

醍醐寺の山上伽藍はすべて大坂で木造をして、現地では「取合

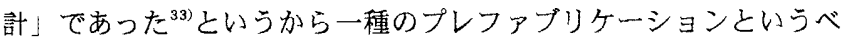
き工法がこの時点ですでに確立し、これが作事の迅速化を生み出し ていたことがわかる。このように寺家大工や社家大工に比べ、「上 人大工」「奉行の大工」「秀頼様御大工」は建築生産方法と設計能 カに優れていた。

源左衛門が秀頼造営の寺社に関する史料に名前を残すのは醍醐寺 山上伽藍だけであるが、『慶長日件録』慶長十二年十月二十五日の 条に、「大工源左衛門、自駿河帰、」とあり、駿府城作事に参加し たものと思われる。また、源左衛門は慶長十八年(1613)の慶長度内 裹造営の時中井正清配下の棟梁として名前が見え ${ }^{35)}$ 、元和五年 (1619)の女御御殿造営にも同じく名前が見える ${ }^{36)}$

和泉守・但馬守 慶長十二年(1607)の住吉大社作事で亀屋与左衛 門らとともに参加している大工に和泉守と但馬守がいる ${ }^{37}$ 。和泉守 は净土寺本堂、但馬守は神宮寺の西塔と両三昧堂を担当している。 東塔は亀屋与左衛門の担当であり、和泉守・但馬守は、秀頼造営寺 社を数多く手がけている亀屋与左衛門に並ぶような実力を持ってい た大工であったと考えられる。当時、貝塚の願泉寺を本拠とする願 泉寺大工は優れた大工集団として有名であったが、その棟梁である 岸上氏に但馬守、和泉守という受領名を持つ岸上定吉、貞由兄弟が いる ${ }^{38}$ 。住吉大社作事に従事したのは彼等であったと思われる。
願泉寺大工集団が秀頼造営の寺社に関わつた例は、他に慶長九年 (1604)の聖神社造営があげられる。聖神社は本殿や宮殿から「泉州 南郡海塚の御坊大工衆」「泉州南郡海塚御坊口町大工二左衛門」と いう墨書が発見されているが39?、「海（貝）塚御坊」というのは、 一時本願寺でもあった願泉寺のことである。また、未社三神社から 「河内国茨田郡十七ヶ所 二兵衛作」、未社滝神社加ら山城国 $\square$ $\square$ 郡下京住人 $\square$ 兵衛是於才敷也」という墨畫が発見されており ${ }^{40)} \mathrm{A}$ 方式の作事であったとわかる。A方式であれば御坊大工衆、いわゆ る願泉寺大工集団の棟梁であった岸上但馬守定吉、岸上和泉守貞由 が作事に参加している可能性はたいへん高いと言えよう。

和泉守が造営に携わった建築物としては他に寛文三年(1663)の願 泉寺本堂が知られているが41)、17世紀後半の建築であるにもかかわ らず、構造は古式を守り、彫刻も古式で、摹股彫刻も輪郭からはみ 出さず彫刻にも崩れがみられない。もともと願泉寺大工は彫刻技術 の高さで知られ、聖神社にもそれが窥われる。

喜多越後守清次 喜多越後守清次は、慶長八年(1603)の休岡八幡 神社作事に棟梁として子息助作や脇棟梁善右衛門らと共に携わって おり、棟札には「五条村大工座之随一也」とある ${ }^{42}$ 。五条村は薬師 寺領の中でも一番大きな集落で、多くの薬師寺番匠が住んでいた ${ }^{433}$ ことから、清次も元は薬師寺大工であったと思われる。

清次も源左衛門と同じく、慶長度内裹作事において「大仏 喜多 越後」と中井配下の棟梁として名前を見ることができる ${ }^{44)}$ 。共に名 前のある「大仏 助作」はあるいは休岡八幡神社棟札にある子息助 作かもしれない。慶長度内裹では全殿舎を $100 丁$ 場にわけ、それ ぞれに奉行を配し、その下に数人づつの棟梁をつかせ、さらに頭棟 梁格の者を $2 、 3$ 名加えて作事に当たらせている ${ }^{45)}$ 。この 10 丁場 のうち喜多越後は 8 丁場までその任に当たり、内裹の大部分の工事 を実際に行ったと思われる。喜多越後以外の頭棟梁は西里村の辻本 若狭、東里村の金藏など法隆寺大工で、彼等は早くから中井配下の 棟梁であったと思われ、そのなかで頭棟梁の一人となった喜多越後 が如何に技術的に優れていたかの証左となろう。

元和五年(1619)の慶長度内裹女御御殿作事には、大仏越後として

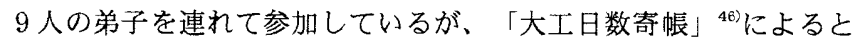
すべての大工のなかで最高の一日 8升の給米を受けている。

森田和泉守重次 前述したように、慶長十二年(1607)の北野天満 宮作事の棟梁である。「慶長十二年造営遷宮記録」 ${ }^{47} に$

一、同十三日、御社頭ノ棟上有、此間大工五郎左衛門と又弁慶 と公事有之いへ共阔方へ落不付して、秀賴様御大工和泉といふ 大工つちをうつ也、（以下略）

とあり、「春賴様御大工」と記されている。しかし、森田和泉守重 次は、北野天満宮以外の史料にその名を見い出すことはできない。 『北野社家日記』慶長十七年十月九日の条 ${ }^{48)} に$

一、（略）柱何かさうさ共、秀頼様御大工泉と申仁又八御さ うくうノ奉行あら木勝太ト申仁両人より皆さうさ被仕候、

と、再び「秀頼様御大工泉」という記述が見えるので、少なくとも 慶長十七年(1612)の時点までは秀頼の御大工の一人であったことは 確かである。

藤右衛門 秀頼が造営した寺社の棟札に藤右衛門という名がタえ るのは、慶長八年(1603)の中山寺棟札 ${ }^{49} の 「$ 御大工藤右衛門」と 
慶長十年(1605)の吉野水分神社の棟札 ${ }^{50)}$ の法隆寺／御大工藤右衛 門尉秀次藤原朝臣」である。このうち、吉野水分神社の棟札の藤右 衛門を、「御大工」「藤右衛門」とあることから中井正清とする意 見がある51)。しかし、「正清」でなく「秀次」であり、棟札に「御 大工」と記されるのは正清ばかりではない。さらに、正清が棟梁を 勤めたことが明らかである、慶長十一年(1606)の法隆寺東院伝法堂 の棟札 ${ }^{52} に は 「 一$ 朝等棟梁 㰌朝臣中井大和守正清」とあり、正清

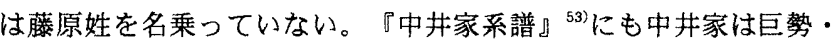
㰌姓であると記されている。従って正清以外に藤右衛門を名乗る法 隆寺大土がいたと考えたほうが妥当であろう。

また、記録類にも藤右衛門という名が散見できる。『北野社家日 記』慶長十二年(1607)八月六日の条には「片市殿大工とうりやう藤

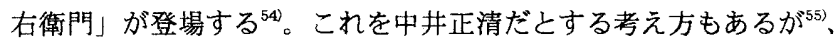
正清が「藤右衛門」を称するのは大和守受領までで、大和守を受領

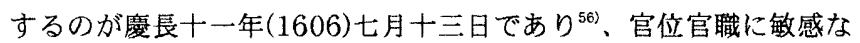
北野天満宮の松梅院禅昌が 1 年以上もたつのにその事実を知らない のは不自然である。さらに、「片市殷大工とうりやう藤右衛門」が 北野天満宮を訪れたという日に正清は京にはいなかった ${ }^{57}$ 。すなわ ち『北野社家日記』慶長十二年八月六日の条に

今夜片市殿とうりやう藤右衛門来、かり殿さしつ松梅院次第二 仕候へと被仰付、荒木勝太方 状有、加殿八法花堂二後用こ とく二申付也、

とあり夜に藤右衛門が上洛し、翌七日には

今日かり殿さしつ究候て大工下申候、

と七日に帰ったことがわかる。しかし、慶長十二年八月八日付の中 井正清の 松梅院にあてた書状 ${ }^{58} に$

如仰下国仕候砌、不能洋顔候、（中略）何樣臨而罷登可得其意 候

とあるので藤右衛門が中井正清でないのは明らかである。もちろん この書状の差出人は「中井大和守」である。

さらに、住吉大社造営に関して『住吉松葉大記』に出てくる藤右 衛門も、この記録が元禄年間の成立であり、和泉守と但馬守が受領 名で記されていること ${ }^{59)}$ 、造営の日付が慶脣十二年(1607)二月十日 と三月二十一日と、正清の大和守受領後であることから中井正清で はないと考えられる。

このほか、内藤昌氏と渡辺勝彦氏が新出史料として紹介された 「御配当半分御取替之事」 ${ }^{60}$ に載る「御大工 藤右衛門」も、中山 寺棟札の「御大工 藤右衛門」とともに、後述するように中井正清 が豊臣氏との関倸が薄いとすれば、秀次の可能性が高い。これらの 藤右衛門がすべて吉野水分神社の棟札に書かれる藤右衛門尉秀次で あれば、藤右衛門秀次は、秀頼の作事組織にとって重要な大工の一 人であったことになる。

以上A方式の場合、比較的小規模の作事では、複数のの大工がそ れぞれの大工集団をひきいて、個別に棟梁を勤めていた。そして、 大規模作事では、一つ一つの大工集団の規模があまり大きくないた めか、共同で作事にあたっていることがわかる。さらに、それらの 大工を運営上統括したのは片桐且元であるが、正清のような御大工 頭㤝存在しなかったことも窥える。

\section{4.秀頛の作事数懽}

豊臣秀頼の作事組織が、初期においては秀吉の作り上げた組織を そのまま受け継いだであろうことは間違いない。では、秀吉の作事 組織とは如何なるものであったのか。秀吉は城郭作事では、安土城 の手伝い普請の時、職人を三交代で作事に当たらせ効率化をはかっ たり ${ }^{61} 、$ 聚楽第造営の時にはそれぞれの殿舎ごとに奉行、棟梁、大 工を決めて工事の組織化と迅速化をはかったりしている ${ }^{62)}$ 。伏見城 に関する記録はないが、肥前名護屋城でも殿舎ごとに担当奉行を決 めて割普請を行っている ${ }^{63)}$ 。しかし、大工に関しては恒常的な組織 があったのか、作事ごとに組織されていたのかは全くわかっていな い。天正十四年(1586)時点で秀吉に「殿下之御大工右衛門尉」がい たことが判明しているが ${ }^{64)} 、$ 彼がどのような役割をはたしていたの かは明らかではない。そのような中、少なくとも秀吉の寺社作事の 統括者が応其であったことは確かである。勧進聖である応其は、数 多くの高野衆や各地から集めた何百人もの大工をひきいて、方広寺 大仏殿ばかりではなく、洛中洛外の寺社の大規模造営・整備に当た つた ${ }^{65)}$ 。大仏大工」「上人大工」などと称する彼等は応其を中心 とした統一的組織であったと思われ、豊臣政権の行政機構のなかに 完全に組み込まれていたわけではないが、実質上、寺社造営におけ る豊臣家の作事組織として機能していたと考えられる。

しかし、これまでみてきたように、秀頼の寺社再興において、A 方式以外に寺家大工や地元の大工によるB方式の作事が広篂围に存 在している。また、秀頼側の大工が作事を行う場合でも、複数の大 工が個別に棟梁を勤めていて、それらの大工棟梁には明確な上下関 係は認められず、並列関係にあったと思われる。この様に作事組織 が変化した背景としてはさまざまな要因が考えられる。

秀頼にとってごく初期のA方式の作事である豊国廟と醍醐寺金堂 造営では、応其が高野衆とともに作事の監理を行っている。おそら くは、慶長五年(1600)の関ヶ原の戦いまでは秀吉の作事組織がその まま機能していたに違いない。しかし、関ヶ原の戦いの後、責任を 家康に問われて応其は隐遁する。その後を文殊院势誉が引き継ぎ、 慶長十一年(1606)の南椫寺法堂作事まで秀頼の寺社造営に関与はす るが66)、実際造営に奉行としてかかわったのは東寺金堂と南大門の みである。秀吉の死後、豊臣政権が大きく弱体化するのは、政治的 には豊臣政権自体の構造的矛盾、集権派と分権派の対立などが指摘 されているが ${ }^{67}$ 、豊臣政権が秀吉と諸大名の個別的関係という基盤 の上に立脚していたこともその原因の一つであろう。同様に、少な くとも秀吉の寺社造営における作事組織は、秀吉と応其という天正 十三年(1585)の高野攻め以降密接に続いた関係に依拠していたが為 に、秀吉の死と応其の隠遁で事実上解体してしまうのである。しか し、寺社造営における作事組織のみが秀吉の作事組織であったわけ ではなく、それだけでは豊臣家の作事組織の変貿の理由とはならな w。

秀頼と秀吉の造営した建築物には大きな相違点がある。秀吉が大 坂城、肥前名護屋城、伏見城、聚楽第など次々に造営したのに対 し、秀頼は城郭の造営を一度も行っていない。寺社においても、秀 吉が、方広寺を初め祥雲寺、天瑞寺、青厥寺と寺院を創建したのに 比べ、秀頼は、豊国廟、法国寺、大坂豊国神社以外标すべて再興、 または修理である。これらの違いが生まれた背景のひとつとして、 
豊臣氏のおかれた政治的立場を看過することはできないだろう。関 ヶ原の戦い以降、豊臣家は事実上提河泉 65 万石の一大名になって しまう。そして「公儀」の実権は家康に移る。慶長九年頃加ら慶長 十一年(1606)まで続く金剛寺作事では、豊後や薩摩から職人を多数 動員していて ${ }^{68)}$ 、依然西国大名に对しては大きな影響力を持ってい たと思われるが、慶長十一年の江戸城作事で初めて秀頼領から、片 桐且元を介してではあるが国役動員がかけられる 城郭にしても寺社にしても一からの造営であった為、大量の職人の 投入を必要とした。しかし、秀頼の行った寺社再興では、奉行と大 工を派遣するA方式の作事の場合でも、権門寺社には寺家大工が存 在していて、ほとんどが共同作業となっている。これは豊臣領以外 からの普請役の動員力の低下と無関保ではないと思われる。

秀頼の再興する寺社が急に減少するのは慶長十三、四年以降であ る。慶長十六年(1611)にはいわゆる二条城会見が行われ、秀頼は徳 川氏に対して臣下の礼をとる。続いて禁褁造営という大義名分の下 に秀頼の家臣も含めた諸大名に普請が課され、ここに徳川幕府とい う、秀吉の「公儀」に依捰しない、新しい権威による国役動員体制 が確立する ${ }^{70)}$ 。さらに、この時点で秀頼の作事に大きな役割を果た してきた源左衛門、喜多越後守清次の両名を配下にしているなど、 中井正清の五畿内近江六ヶ国の大工支配も着々と進んでいた。そし てそのような状況下、豊臣家の作事であるにもかかわらず、第 2 次 方広寺大仏殿は中井正清を棟梁として進められるのである。

従来『捸陽奇観』 ${ }^{71}$ 『真書太閤記』 ${ }^{72}$ に大坂城の棟梁が中井正清で あるとすること、豊臣氏大坂城の指図が中井家から見つかったこと から中井正吉が大坂城築城に大きな役割を果たし、『愚子見記』 ${ }^{73}$ の記述より方広寺大仏殿造営では正吉が「棟梁司」であった、故に 正吉は豊臣氏に仕えていたと考えられてきた。さらに、正清も最初 は父とともに豊臣氏に仕え、秀頼の作事にもかかわってきたと考え られてきた ${ }^{74)}$ 。正吉が大坂城作事の御大工であったことを否定する ものではないが、秀吉期の 1 次史料にまったく正吉の名を見い出せ ないのは事実であり、天正度方広寺大仏殿作事で後の江戸幕府作事 における正清のような役割を担っていたのは応其である ${ }^{75}$ 。

正清が豊臣家の御大工であったという 1 次史料はなく、少なくと も秀頼期の豊臣氏とはそれほど深い関係はなかったのではないだろ うか。中山寺、吉野水分神社、住吉大社、北野天満宮の藤右衛門を 秀次だとすると、正清が秀頼の作事に関与したのは法隆寺大修理と 慶長度方広寺大仏殿だけとなる ${ }^{76\rangle}$ 。法隆寺大修理は法隆寺大工を束 ねる棟梁として当然の人選である。慶長十一年(1606)八月の法隆寺 棟札 ${ }^{77)}$ の一朝㗙棟梁」という文字には、徳川氏の御大工頭であっ た正清が、まだ権威の残存していた豊臣氏からも棟梁として作事を 任され、しかもこれに先立つ七月十三日には従五位下大和守に叙任 されたという正清の得意の絶頂を見ることができる。

また、方広寺大仏殿作事に正清が当たったのは、秀頼の作事体制 に問題があったことも一因ではないか。見てきたように秀頼の作事 組織には、大規模造営には不可欠である応其のような作事編成能力 を持った人物が存在しなかった。さらに広域動員、および全国から の資材の調達が困難になり、大仏殿という巨大な建築物を建造する ための構造技術を持った大工がいなかったと考えられる。徳川幕府 御大工頭の中井正清が方広寺大仏殿作事の棟梁を勤めたのは、家康 の思惑 ${ }^{78}$ があったのは言うまでもないが、豊臣氏と中井正清の個人
的な結び付きからではなく、広域動員体制を掌握し、優秀な技術陣 を多く抱えていた徳川幕府の大工である正清にしかできない作事だ ったからではないだろうか。このように慶長期後半には豊臣氏の組 織は脆弱化し、方広寺大仏殿は幕府の作事組織に頼らなければ造営 できなかったのである。

\section{5.おわりに}

秀吉の死後豊臣氏の政治的立場は大きく変化していく。それとと もに秀頼の再興する寺社は変化し、秀吉から受け継いだはずの作事 組織も変質を余儀なくされる。おそらくは 100 を超える多くの寺 社を再興したにもかかわらず、その作事体制には限界が窥兑、それ どころか、秀頼の作事組織が組織として十分に機能していたかとい う疑問が残る。

当然のことながら、秀頼の寺社造営を支えた大工は技術的にも均 一ではなく、これら雑多なエネルギーが秀頼の寺社作事の原動力で もあった。これは中井正清という一人の傑出した人物の下、組織化 され安定した技術力を保持し、一定のレベルの建築を次々と造り出 して行った徳川幕府の作事組織とは大きく異なる。しかし、逆に一 元化されなかったことが、秀頼の造営寺社における建築および建築 彫刻の多様性を生む。各地の東照宮のように徳川家造営の寺社の建 築䧓刻が定型化に陥ったのに比べ、1 7 年という短い間であった が、多様性を誇る秀頼造営寺社の建築彫刻梳、桃山建築彫刻の中で もひときわ光彩を放つものであるといえよう。この秀頼造営寺社に おける建築彫刻の問題については次稿に譲りたい。

\section{謝辞}

本研究に際し、京都橘女子大学教授横田冬彦氏と神戸大学工学部助 教授黒田龍二氏に多くのご教示を賜わった。記して感謝の意を表す る次第である。

\section{[墪]}

1）政治史では天正元年（1573）から慶長五年（1600）までを桃山時代とす るが、ここでは建箘史及び美術史の区分に従い、下限を元和元年（1615） とした。

2）拙稿「豊臣秀頼の寺社造営について」（『日本建筑学会論文報告集』第 499号 1997年)

3）横田冬彦「近世都市と職人集団」（『日本都市史入門吕 人』東京大学出 版会 1990年)

4）桜井景雄・藤井学共編『南禅寺文書 中巻』（南禅寺宗務本所 1974 年） 333 号、335号、343号 片桐貞隆書状、339号、340号 片桐且元書状 等

5 ）鈴木武雄『大井殹御坊慈眼院』（大井堰御坊慈眼院寺務所 1984年）大 井関大明神鹿長造営記録木札

6）『重要文化財泉穴師神社々殿修理工事報告書』1958年

7）『国宝観心寺金堂・重要文化財建挂塔修理工事報告書』1984年

8）前揭註 7)

9）『石山寺多宝塔修理要録』所掲

10）『国宝都久夫須麻神社修理工事報告書』1937年

11）『東浅井郡志 巻 3 』雑志第 2 編第 4 章第 4 節、『東浅井郡志 巻 4 』 古文書志第 1 編郡内操集文書 阿部文畫、1927年

12）『義演准后日記』（『史料算集』古記録編 1984年）慶長五年四月十八 日の条

13）『北野天満宮史料・古文畫』（北野天満宮史料刊行会 1978年）睥長十 二年造営遉宮記録

14）本正夫「片桐且元と慶長の修理」（『月刊文化財』151号 1978年） 藤井直正「豊臣秀頼の寺社造営とその遺構」（『大手前女子大学論集』1 7 集 1983年）所掲 
15）『住吉松葉大記』（復刻版 皇学館大学出版部 1984年）巻第21 造觉 部 廖長十一年の条

16）もっとも、この五重塔作事は、当初は応其が道接作事に当たるA方式の 予定であったが、大仏殷作事と重なり、やむなくB方式に变更。最後に は、秀吉の花見のために再度 $\mathrm{A}$ 方式に变更して竣工する。『義演准后日 記』（『史料算集』古記録編 1984年）穈長二年二月十七日、六月五日、 十一月十日、十二月二十七日、慶長三年一月五日、二月九日、二月二十九 日の条など。

17）『義演准后日記』（『史料算集』古記録編 1984年）慶長三年九月二十 四日、十月四日、慶長五年一月四日、慶長六年十二月二十五日の条など。

18）『義演准后日記』（『史料簱集』古記録編 1984年）慶長三年四月二十 七日、五月十九日、慶長五年三月六日、三月九日、三月十一日、三月二十 二日、四月十八日の条など

19）『義演准后日記』（『大日本史料』慶長十一年六月二十四日）磨長十一 年十月朔日、同年十一月九日の条など。

20）金堂の東北隅木墨書に「此角ヨリ西南大工棟梁但馬国住人藤原助左衛門 大和国口口大納言秀長御大工地」とあり、秀長御大工の関与が認められ る。（文化庁監修『国宝 14 建造物 II』1984年 所揭）

21）翌暦長六年に山岡道阿弥によって建てられた光浄院客殿と外観、平面と もたいへん似ていることはよく知られているが、再興者が異なるのに共通 しているというのは共に寺家大工が手がけた可能性がある。

22）片埜神社、二宮神社とも楝札が現存している。（『大阪府神社文化財目 録』大阪府神社庁 1981年、『特別展 豊臣秀頼展』大阪城天守閣 1993 年、所揭)

23）伊居太神社、吳服神社とも棟札が現存している。（『池田市史 史料編 (1)原始・古代・中世』1967年 所揭)

24）『重要文化財金剛寺食堂修理工事報告書』1955年、『大阪府の近世寺社 建筑一近世寺社建築緊急調查報告書』（大阪府教育委員会文化財保護課 1987年)

25）『重要文化財金剛寺食堂修理工事報告書』1955年

26）前揭註25)

27) 前掲註 15)

28）梅園惟朝著、元椂（1688 1704）ごろ成立か

以下住吉大社作事について㹥『住吉松葉大記』（復刻版 皇学館大学出版 部 1984年）巻第21 造営部 慶長十一年の条による。

29）前揭註 25）

30）『棟札銘文集成一中国・四国・九州編一』（国立歴史民族博物館 1993 年)

31）『義演准后日記』（『大日本史料』慶長十一年六月二十四日）晨長十一年 十一月九日の条

九日、陰、番匠源左衛門来、山上三伽藍、此番匠地ワリ等仕之、大仏十 人棟梁之中也、

32）『慶長日件録』（『日本古典全集』日本古典全集刊行会１939年、 『史料算集』古記録編 1981年）慶長八年十一月十九日の条

大工源左衛門予也披官分二可成由、令契約来、樽両種進之、内義へ折 進之、向後可令奉公云々

33）『義演准后日記』（『大日本史料』慶長十一年六月二十 四日）慶長 十一年十月一日の条

34) 前揭流3)

35）吉田純一平井聖「慶長〜元和期に扮ける中井正清配下の棟梁」（『日 本建筑学会論文報告集』第333号 1983年)

36）『元和五年正月ヨリ六月迄 禁中女御様御作事仕大工日数寄帳 大仏 优見 東福寺 山城』（宮内庁畫陵部）

37）前揭註 15)

38）『貝塚䧓物大工由緒書』[願泉寺文書 1000 号]（頕泉寺蔵 天保十一年 (1840) 以前成立加)

39）『国宝聖神社本殿修理工事報告書』1938年

40）『重要文化財聖神社末社三神社滝神社修理工事報告書』1979年

41）『了観師記 万記録』（『日本都市生活史料集成 9 門 前町篇』学習 研究社 1977年) 卜半了観著、延享三年（1744）成立

42）『奈良県史 第 17 巻 金石文 (下)』1987年

43）大河直躬『番匠』（法政大学出版局 1971年）第10章

44）前揭註 35)

45）平井聖・鈴木解雄「江戸時代に打ける京都御所造営史概説一－I（慶長度 禁豪造営における造営組織について）」（『日本建築学会研究報告』第 43 号 1957年)

46）前揭註 36)

47）『北野天満宮史料・古文書』（北野天満宮史料刊行会 1978年）

48）『北野社家日記』第六（『史料算集』古記録編 1973年）
49）『宝塚市史 第 5 巻 資料編 1 1978年

50）『重要文化財吉野水分神社择殿幣殿修理工事報告書』1976年、『重要文 化財吉野水分神社楼門・迴廊修理工事報告書』1987年、所揭

51）紐見啓三「大和における近世大工の動向」（『奈良県の近世寺社建築』 奈良県教育委員会文化財保護課 1987 年 所收）

52）『日本建筑史基礎資料集成4 仏堂 I』（中央公論美街出版 1981年）

53）城戸久解題『中井家系譄』（私家版 1951年）

54）「片市殷大工とうりやう」を文字ど㧍り、片桐且元の被官大工ととるこ ともできるが、ここで性奉行派䢥の大工と解釉したほうが妥当であると思 われる。

55）平井聖「中井家と中井家文書」（『中井家文畵の研究 1 』中央公論美術 出版 1976年)

56) 前揭註53)

57）横田冬彦「中井正清の居所と行動」（『近世前期政治的主要人物の居所 と行動]京都大学人文科学研究所調查報告 第37号 1994年)

58）『北野天満宮史料・古文書』（北野天満宮史料刊行会 1978年）179号 中井正清書状

59）前揭註15)

また、『貝塚大工之由緒畫』（䝠泉寺蔵）によると、但馬、和泉は直江山 城守の高野山金剛峰寺の小塔再興の折に大党寺宮から受領したものである という。金剛峰寺の小塔再興がいつなのかはかからないが、上杉暴勝の家 臣である直江山城守兼続が死去するのは元和五年（1619）なのでそれ以前 と考えられる。

60）内藤昌・渡辺勝彦「豊臣家御大工藤右衛門について」（『日本建筑学会 大会学術講演梗概集』1984年)

なお、同じく「御配当半分御取替之事」に載る「御大工与左衛門」は亀屋 与左衛門の可能性がある。

61）天正五年六月五日付豊臣秀吉自筆書状（『特別展 戦国の五十人』大阪 城天守閣 1994年 所揭)

62）天正十四年十月二十二日付豊臣秀吉朱印状（『特別展戦国の五十人』大 阪城天守閣 1994年 所揭)

63）内藤昌「肥前名讙屋城図屏風」の建築的考察」（『国華』915 1968 年)

64）『兼見卿記』（東京大学史料編算所藏）天正十四年八月二十四日の条

65）『高野山文書』（『大日本古文書』家わけ第一）491号 諸寺諸社造営目 録

66）桜井景雄・滕井学共編『南禅寺文書 中巻』（南禅寺宗務本所 1974 年) $341 、 342$ 号 文殊院势誉書状

67）朝尾直弘『将軍権力の創出』（岩波書店 1994年）

68）前揭群25)

69）高橋正彦編「大工頭中井家文書」（史学39 1967年）大久保長安 · 本多正純連署書状

70）高木昭作「江戸幕府の成立」（岩波辝座『日本歴史 9 近世 1 』岩波㫪店 1975年)

71）浜松歌国著、文政 I 0 年（1827）ごろ成立か

72）栗原信充著、12編36巻、嘉永以降順次刊、明治17年（1884）完成。

73）今奥政隆著、寬文11年（1671）～貞享元年（1684）成立 （復刻版 井上書店 1989年）

74）内藤昌『近世大工の系譜』（ペりかん社 1981年）、波辺勝彦「城郭と 内串の造営!（『講座日本技術の社会史 第 7 巻建策』日本評論社 1983年)

75）横田冬彦「中井正清一棟梁たちをひきいた大工頭」（『譜座 日本技術 の社会史 別巻 1 人物編 近世』日本評論社 1986年)

76）辻善之助氏は中井正清がかかわった相国寺山門を豊臣秀頼の造営とする が（过善之助『日本仏教史 近世編之二』岩波書店 1953年）、「西笑和 尚文案」（『大日本史料』慶長十一年二月十五日）によると德川家康の造 営である。

77）前揭住52)

78）中井正清が「公儀の大工」として大仏殿再建を行うことにより豊臣体制 の残存していた銓物師や大仏大工をその元に完全に編成し幕府の瞕人掌握 を進めようとした。（前揭註3）、高木昭作「幕藩初期の身分と国役」『歴 史学研究』別冊1976年)

（1998年1月10日原稿受理，1998年3月16日採用決定） 